\title{
Antimicrobial activity of fungi isolated from the water of the sky high, Recife-PE supply against bacteria of clinical interest system
}

Talyce dos Reis Feitosa ${ }^{1}$, Flavia Virgínia Ferreira de Arruda ${ }^{2}$, José Robson Neves Cavalcanti Filho $^{2}$, Nelânia Maria Queiroz Baptista ${ }^{2}$, Maira Judith de Azevedo Callou ${ }^{2}$, Tiago Silva ${ }^{2}$, Rita de Cássia Mendonça de Miranda ${ }^{2,3 *}$ and Norma Buarque de Gusmão ${ }^{2}$

\author{
${ }^{1}$ Instituto Federal do Tocantins, campus Araguaina, Tocantins, Brasil. \\ ${ }^{2}$ Departamento de antibióticos, Universidade Federal de Pernambuco, Recife/PE, Brasil. \\ ${ }^{3}$ Faculdade do Nordeste da Bahia, FANEB, Brasil.
}

\begin{abstract}
Water supply assumes an important role, since it can serve as a vehicle for microorganisms such as viruses, bacteria and pathogenic fungi. The presence of a group of microorganisms (fungi) that cause deterioration of water quality is related to the production of secondary metabolites, such as antibiotics and toxins. One of the reasons of carrying out tests with these organisms is, among other things, to verify their antimicrobial activity against other pathogens. From this, five fungi species isolated from the Water Supply System of High Heaven (Pestalopsis palestris, Cladosporium cladosporioides, Trichoderma pseudokoningii, Curvularia lunata (50) and Penicillium sp. (45)) were tested against the bacteria of clinical interest (Staphylococcus aureus (UFPEDA 01), Pseudomonas aeruginosa (UFPEDA 39), Mycobacterium tuberculosis (UFPEDA 71)) and three oxacillin-resistant S. aureus ( ORSA UFPEDA 709, $730,733)$ using the disc diffusion method. It was observed that the extract of Penicillium sp. showed antibacterial activity against $S$. aureus (730 ORSA).
\end{abstract}

Key words: Test activity, filamentous fungi, Staphylococcus aureus (ORSA).

\section{INTRODUCTION}

Microbiological quality is expressed by the amount of bacteria present in a given volume of water (Hageskal and Skarar, 2008), but in recent decades, viruses and other parasites have also been accepted as quality parameters. Some studies have reported the occurrence of filamentous fungi in drinking water, but their quanti- fication is still small compared to bacteria (Paterson et al., 2005). But, there are already reports of fungi causing nosocomial infection with water as a vector. Pereira et al. $(2009,2010)$ reported the occurrence of several species of fungi in various sources of drinking water. In addition to this study, 49 different species of fungi were identified as

*Corresponding author. E-mail: ritamend30@gmail.com. Tel: 55 (79) 34293812.

Author(s) agree that this article remain permanently open access under the terms of the Creative Commons Attribution License 4.0 International License 
producers of toxins and metabolites.

Secondary metabolites in nature are important for microorganisms that produce them; they work as sex hormones, ionophores, competitive weapons against other organisms, are symbiotic agents and have effects of differentiation and unknown activities (Demian and Adrio, 2008)

In nature, organisms are organized in biofilms known to be composed of complex communities of organisms, including aerobic and anaerobic bacteria, amoeba, protozoa, nematodes, and fungi. The microorganisms that reside near and synergistically live in biofilm support the fungi or nutrient source for bacteria, thus contributing to biofilm formation (Fachin et al., 2001). Many organisms comprising biofilms produce metabolites with other organizations, using antibiosis as a defense mechanism of the microbial community. These metabolites can inhibit the growth or kill the organism that causes damage to the biofilm structure (Silva et al., 2006; Wilson et al., 2011.)

The bacteria, Staphylococcus aureus is an important pathogen because of its virulence, antimicrobial resistance and association with several diseases, including lifethreatening systemic diseases, skin infections, opportunistic infections and food poisoning. Antimicrobials are drugs that have the ability to inhibit the growth of or kill pathogenic microorganisms, without being toxic to the host (Tortora, 2000; Griffin, 1993).

Despite the availability of a large number of antibiotics in the last generation, it is very important to seek compounds that may act as new drugs for fighting diseases caused by bacteria (Bills et al., 2013). Numerous studies have reported the antimicrobial resistance of $S$. aureus bacteria. Thibaut etal. (2010) reported that S. aureus and Escherichia coli isolated from food bacteria were resistant to antibiotics group $\beta$ - lactams and macrolides. Ferreira et al. (2011), investigating the presence of methicillin- resistant $S$. aureus on the surface of various objects in an intensive care unit, found that 29 samples ( $60.4 \%$ ) were resistant to methicillin. The authors emphasized that the surface area of the infusion pump and aprons was infected by 60 and $75 \%$ respectively of the isolated samples. Catão et al. (2013) documented the rate of hospitalized patients with various infections in a hospital in Campina Grande, Paraíba, Brazil. Of the 1056 charts reviewed, 26 reported infections caused by S. aureus. Of these, 17 reported cases of methicillin-resistant Staphylococcus.

Another determining factor is the optimization of the culture media for the production of secondary metabolites by microorganisms isolated from diverse environments. One technique currently used is the experimental design, an effective tool for statistical optimization of fermentation processes. Some authors have reported the use of this methodology for process improvement. De Paris et al. (2012) reported the use of an experimental design (CCR) with twenty two runs for optimization of the culture medium of Aspergillus niger in solid state fermentation.

Given all, the above aims to evaluate the antimicrobial activity of fungi against bacteria of clinical interest, using an optimized culture medium.

\section{MATERIALS AND METHODS}

\section{Microorganisms}

\section{Fungi}

The five fungi, Pestalopsis palestris URM 04; Cladosporium cladosporioides URM 06; Trichoderma pseudokonigii URM 35; Curvularia lunata URM 50 and Penicillium sp. URM 45 isolated from the main supply system of the High Sky in Recife were used (Table 1). These organisms were identified by micro-morphological fungal structures (conidiophores and vegetative structures) observation as well as by biochemical tests; and they were subsequently deposited in the Culture Collection of the URM Culture Collection UFPE.

\section{Bacteria}

In order to test the antibacterial activity of the metabolites produced by the fungi, gram positive bacteria (G+); S. aureus (UFPEDA 01) and S. aureus (ORSA UFPEDA 709, 730, 733); and Gram negative bacteria (G-) (Pseudomonas aeruginosa UFPEDA 39) were used. Mycobacterium tuberculosis (UFPEDA 71) and alcohol resistant acid (ARA) of clinical interest were acquired from the Culture Collection of the Federal University of Pernambuco, Department of Antibiotics (UFPEDA) (Table 2).

\section{Selection of microorganisms}

Before the selection was done, fungal spores were inoculated separately in the center of the Petri dishes containing Sabouraud culture; they were incubated at $30^{\circ} \mathrm{C}$ for $48 \mathrm{~h}$ to obtain the mycelial mass.

In order to test the fungi that produce metabolites against better clinical bacteria, agar discs of approximately six millimeters $(6 \mathrm{~mm}$ $\varphi / 1.5 \mathrm{~g} / \mathrm{L}$ ) and yeast previously grown were inoculated in two ways in potato dextrose liquid culture (PD - $200.0 \mathrm{~g}$ Potato, $15.0 \mathrm{~g}$ glucose and $1.000 \mathrm{~mL}$ of distilled water, $\mathrm{pH} 6.8$ to 7.0 ) and Sabouraud (SAB - $50.0 \mathrm{~g}$ peptone, $40.0 \mathrm{~g}$ glucose, $1000 \mathrm{ml}$ distilled water; final $\mathrm{pH}$ adjusted to 5.6). They were incubated under static conditions for five days. After this period, the filtrate of growth culture was obtained by filtration and tested for antimicrobial activity using the method of Kirb et al. (1966). In this, paper discs (6 mm $\varphi$ ) were soaked in $10 \mu \mathrm{L}$ filtrate of growth culture of the fungus and placed in a Petri plate previously seeded with the standard solutions at $0.5 \mathrm{McF}$ arland scale of bacteria $\left(10^{8} \mathrm{UFC} / \mathrm{mL}\right)$ to be tested. The samples were incubated at $37^{\circ} \mathrm{C}$ for $24 \mathrm{~h}$. After this period, zones of inhibition $(\mathrm{mm})$ were measured. At this stage the five, fungi were tested against $S$. aureus (UFPEDA 01), $P$. aeruginosa (UFPEDA 39) and $M$. tuberculosis bacteria (UFPEDA 71).

\section{Influence of aeration on the production of metabolites}

In order to observe the influence of aeration on the production of metabolites, agar discs (approximately six millimeters) of fungus selected in the previous step were inoculated in the culture medium showing the best conditions for production of metabolite in a 250 $\mathrm{mL}$ Erlenmeyer flasks subjected to $180 \mathrm{rpm}$ at $37^{\circ} \mathrm{C}$. Every $24 \mathrm{~h}$, aliquots were removed for measurement of $\mathrm{pH}$ potentiometer, Model HSP-3B and biomass dry weight by observation method. The influence of stirring was examined by observing the formation of inhibition zones by the methodology described above against oxacillin-resistant $S$. aureus (ORSA). 
Table 1. Fungi.

\begin{tabular}{lc}
\hline Fungi & Identification number (URM) \\
\hline Pestalopsis palestris & 04 \\
Cladosporium cladosporioides & 06 \\
Trichoderma pseudokonigii & 35 \\
Curvularia lunata & 50 \\
Penicillium sp. & 45 \\
\hline
\end{tabular}

Table 2. Bacteria.

\begin{tabular}{lc}
\hline Bacteria & $\begin{array}{c}\text { No. of collection } \\
\text { (UFPEDA) }\end{array}$ \\
\hline Staphylococcus aureus (G+) & 01 \\
S. aureus ORSA (G+) & 709 \\
S. aureus ORSA (G+) & 730 \\
S. aureus ORSA (G+) & 733 \\
Pseudomonas aeruginosa (G-) & 39 \\
Mycobacterium tuberculosis & 71 \\
(AAR) & \\
\hline
\end{tabular}

Table 3. Coded matrix of $2^{2}$ factorial design with three center points for the fungus selected.

\begin{tabular}{lcc}
\hline Tests & Glucose (g/L) & Inoculated \\
\hline 1 & -1 & -1 \\
2 & +1 & -1 \\
3 & -1 & +1 \\
4 & +1 & +1 \\
5 & -1.41 & 0 \\
6 & +1.41 & 0 \\
7 & 0 & -1.41 \\
8 & 0 & +1.41 \\
9 & 0 & 0 \\
10 & 0 & 0 \\
11 & 0 & 0 \\
\hline
\end{tabular}

\section{Optimization of conditions for production of metabolites}

In order to optimize the conditions for the production of metabolites, Statistical Experimental Design methodology was used. With a trend that showed better results in the previous assay, an experimental design was performed in order to obtain the best operating conditions. To this, a central composite design (CCD) was applied, through a full factorial design (22) with levels of -1 and +1 , four axial points $(-1.41$ and +1.41$)$ and three central points (zero level). The variables studied are $\mathrm{pH}$ and agitation (independent variables) and antimicrobial activity (dependent variable). The design consisted of 11 experiments (Table 3 ) and for its realization, we used the Statistic 6.0 Software.

\section{Statistical analysis}

To verify that there was a significant difference between the $\mathrm{pH}$ values and biomass inhibition halo of tested fungi, analysis of variance was performed using the software Statistic 6.0.

\section{RESULTS AND DISCUSSION}

\section{Selection of microorganisms}

Pestalopsis palestris, Cladosporium cladosporioides, Trichoderma pseudokonigil, Curvularia lunata and Penicillium sp. were fermented in two liquid media in static conditions for a period of five days. In the fermentation process, a pH of 6.05 to 7.54 is demonstrated in the Potato Dextrose (PD) medium, which is close to neutral; while in half Sabouraud (SAB), the $\mathrm{pH}$ is 6.76 to 8.76 , which is neutral to alkaline (Figure 1). After the analysis of variance done on the $\mathrm{pH}$ values tested, it was observed that there was no significant difference among the five $\mathrm{pH}$ values obtained with $\mathrm{p}=0.9233$. The $\mathrm{pH}$ is a parameter that should be taken into consideration because of its importance for the continual viability of the fungus during the fermentation process. Pimenta et al. (2008) tested in shake flasks, fungal activity of Hypholoma fasciculare, Saccharomyces cerevisiae yeast (PYCC 4455), Kluveromyces marxianus and Candida tropicalis (PYCC 3886T 3097T PYCC), taking into account the variation of $\mathrm{pH}$ and temperature. They observed that $\mathrm{pH}$ around neutrality (5.6 to 5.8) favored the production of secondary metabolites by the filamentous fungi tested. Bhimba et al. (2012) evaluated the activity of 34 endophytic fungi against various bacteria in liquid medium using the disc diffusion method; they observed that there was increased fungal activity when fermented with acidic $\mathrm{pH}$.

In the production of metabolites, $\mathrm{pH}$ is also important in maintaining the environment of the microorganism, whether natural or synthetic. Many fungi present in biofilms in water systems tend to acidify, creating conditions for their survival. Gao et al. (2013) isolated a fungus, Aureobasidium pullulans from marine biofilm and observed after stimulation, the aquatic environment has a tendency to acidify the saline.

Another factor that must be observed in the processes of production of secondary metabolites by filamentous fungal is that biomass is produced. It must be considered that, as these substances are fruits of secondary metabolism and not directly related to growth, it is more interesting to get a smaller amount of biomass. Throughout the growth stages, there was a higher yield of biomass of the fungus in the culture medium (PD) with values ranging from 0.80 to $4.24 \mathrm{~g} / \mathrm{L}$, showing a good affinity for growth in this medium; whereas in the culture medium (SBA), yield was lower with growth ranging from 0.10 to $1.4 \mathrm{~g} / \mathrm{L}$ (Figure 2). This behavior is due to the alkaline $\mathrm{pH}$ which is not a good condition for growth of fungi. The analysis of variance between the biomass values showed no statistically significant difference between the masses of the five fungi with $p=0.0451$.

Prabha et al. (2009), who also conducted tests on fungi, 


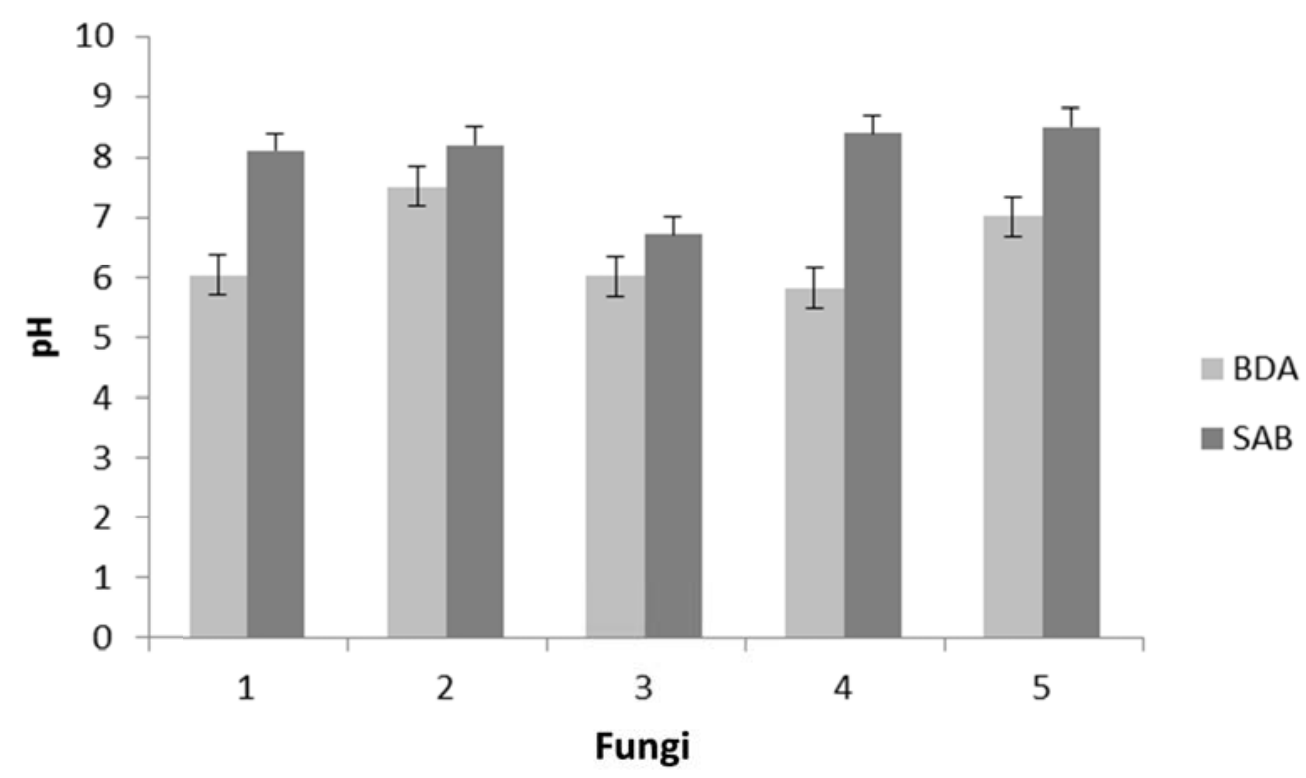

Figure 1. Value of $\mathrm{pH}$ in Sabouraud (SAB) and potato dextrose (PD) of Pestalopsis palestris (1), Cladosporium cladosporioides (2), Trichoderma pseudokonigii (3), Curvularia lunata (4) and Penicillium sp. (5) after five days of fermentation.

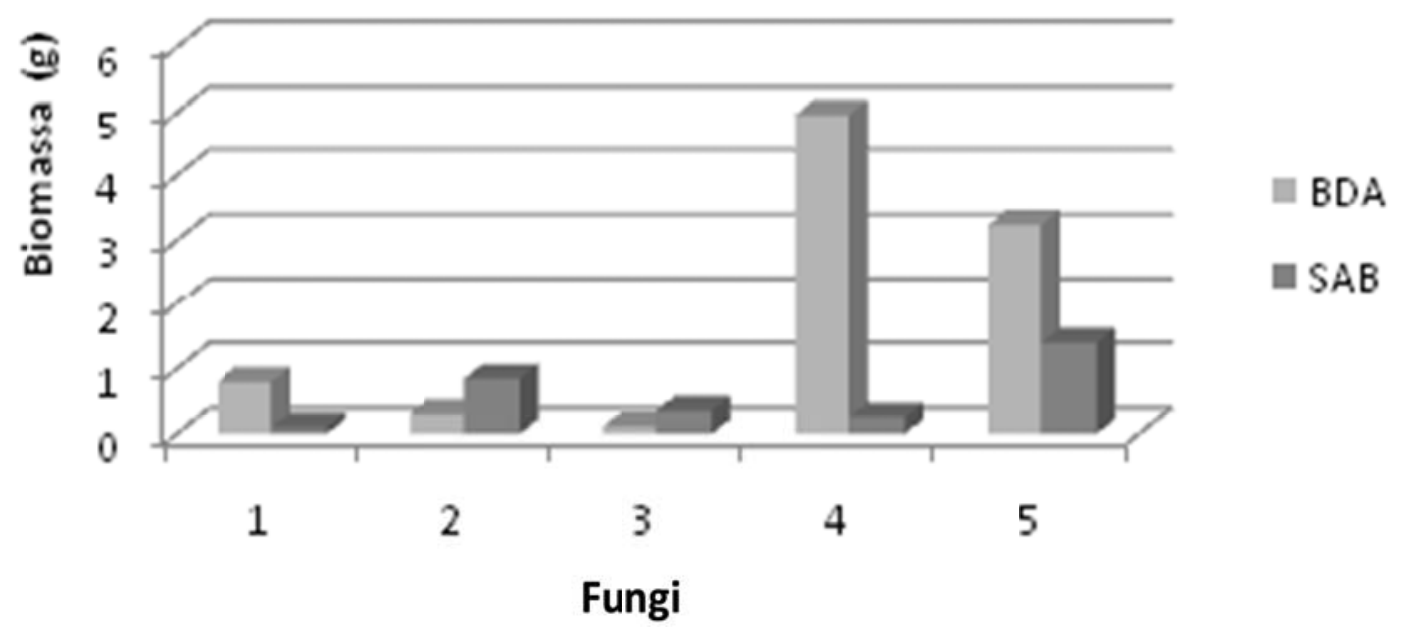

Figure 2. Biomass value produced by fungis Pestalopsis palestris (1), Cladosporium cladosporioides (2), Trichoderma pseudokonigii (3), Curvularia lunata (4) and Penicillium sp. (5) in mediums tested after five days.

observed the growth of Penicillium chrysogenum and Aspergillus sp. These species were grown in liquid fermentation for biomass and secondary metabolites featuring four typical stages of growth: the lag phase (0-7 days) where the physical balance between the microorganisms and the environment showed little growth of 8 to $15^{\circ} \mathrm{C}$. In the log phase, growth occurred with increase of biomass mainly on the 15th day. In the stationary phase of growth, there was altered cell growth medium through the substrate consumption and excretion of secondary metabolites. This is followed by reduction of the biomass in the culture medium, indicating cell deaththe death phase. Also observed was a strong antibacterial activity of citrinin from $P$. aeruginosa bacteria and Vibrio cholera.

The tested Penicillium sp. strain produced metabolites with antimicrobial activity and inhibition zone of $6.5 \mathrm{~mm}$ after $24 \mathrm{~h}$ against $S$. aureus; while other fungal extracts showed no activity against the microorganisms tested. So this fungus was selected to be used in later steps. 


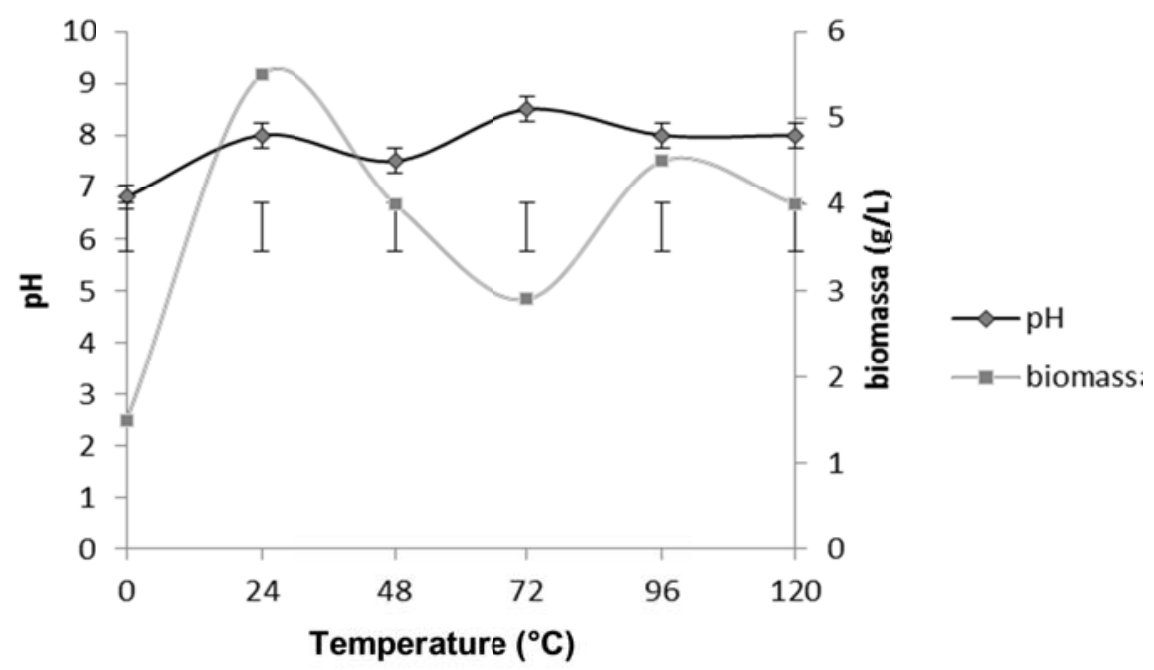

Figure 3. Values of $\mathrm{pH}$ and biomass of fermentation liquid in $\mathrm{PD}$ broth of Penicillium sp. under agitation condition.

Table 4. Inhibition zone of metabolites produced by Penicillium sp. in PD broth.

\begin{tabular}{lccc}
\hline \multirow{2}{*}{ Growth period (time) } & \multicolumn{3}{c}{ Average of inhibition zones (mm) against S. aureus UFPEDA } \\
\cline { 2 - 4 } & 709 & 730 & 733 \\
\hline $24 \mathrm{~h}$ & - & $19,73 \pm 1$ & - \\
$48 \mathrm{~h}$ & - & $20,21 \pm 1$ & - \\
$72 \mathrm{~h}$ & - & $21,80 \pm 1$ & - \\
$96 \mathrm{~h}$ & - & $22 \pm 0.8$ & - \\
$124 \mathrm{~h}$ & - & $22 \pm 0.8$ & - \\
$148 \mathrm{~h}$ & $20.25 \pm 0.05$ & $21 \pm 0.8$ & $16 \pm 0.87$ \\
Vancomicina $\left(\mathrm{C}^{+}\right.$ & $18.3 \pm 0.05$ & $14.2 \pm 0.02$ & $22.09 \pm 0.05$ \\
Caldo BD $\left(\mathrm{C}^{-}\right)$ & 0 & 0 & 0 \\
\hline
\end{tabular}

(-) No activity.

Penicillium species are a group of microorganisms which synthesize high amount of secondary metabolites; in some cases, they have $73 \%$ production more than the other classes of microorganisms. The production of these substances by fungi intrinsically depends on the conditions used for their growth and development (Pepper et al., 2008). In addition, Penicillium species produce a diverse range of active secondary metabolites, including antibacterial, immunosuppressive agents and cholesterol reduction (Petit, 2009). As described since 1929 when Alexander Fleming observed growth inhibition of $S$. aureus in a Petri dish, there was a culture of Penicillium notatum contaminant describing penicillin and its effects on Gram- positive microorganisms (Bauer et al., 1966).

From the results obtained, Penicillium sp. was selected for fermentation in PD broth under stirring condition and by the observation of the influence of this parameter at the middle. After the experiment, it was found that it favored the growth of the fungus. This is because agitation promotes homogenization and increases availability of nutrients from the medium. At the end of the stirring, the fungus grew from 3.96 to $5.03 \mathrm{~g}$, with an anticipation to get better growth at $\mathrm{pH} 8.5$ for $72 \mathrm{~h}$ (Figure 3). Fitsum et al. (2014) tested three species of fungi against Colletitrichum lindemunthianum, the fungus which causes anthracnose of beans. They observed that the activity was higher under agitation conditions (150 rpm) than in static condition. The authors attributed the activity to a better distribution of nutrients in the culture medium.

Table 4 shows the activity of the fungus Penicillium $\mathrm{sp}$. against S. aureus (UFPEDA 709, UFPEDA 730 and UFPEDA 733) tested and their respective standard deviations. The Penicllium sp. was active against $S$. aureus (UFPEDA 730) in the first twenty-four hours in culture while maintaining an increase in this activity over $148 \mathrm{~h}$ with inhibition zones ranging from 19.73 to $22 \mathrm{~mm}$. Although Penicillium sp. has not been shown to be active 


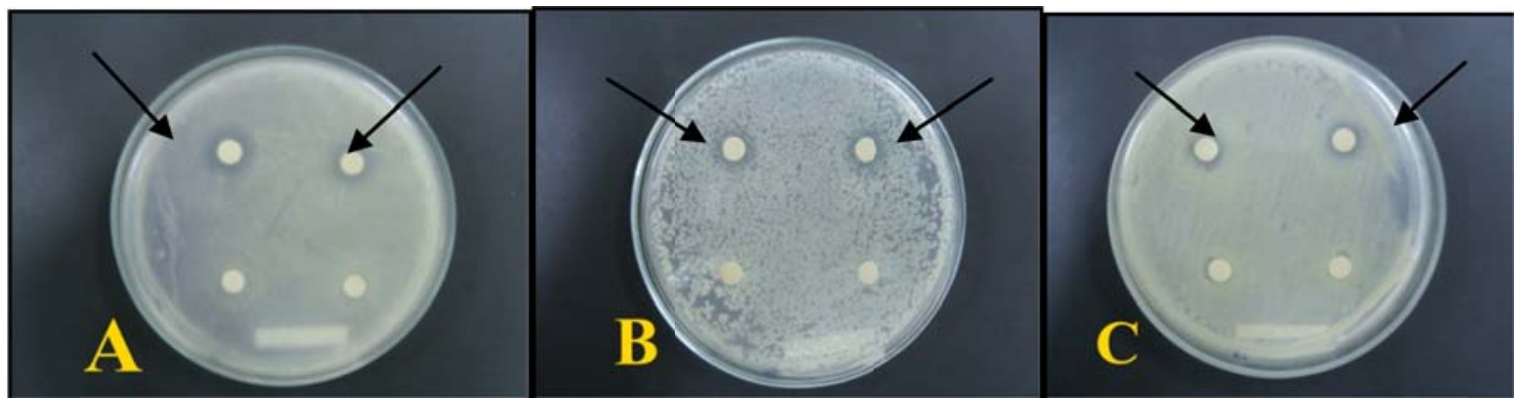

Figure 4. Inhibition formed by the metabolite produced by the fungus Penicillium sp. on PDA against S. aureus 733. Experiments 9,10 and 11 equivalent to the midpoint, respectively.

in the early hours against S. aureus 709 and 733 , there was a significant activity with halos of $20.25 \mathrm{~mm}$ against S. aureus 709; while for $S$. aureus 733 , the halo was $16 \mathrm{~mm}$ after $148 \mathrm{~h}$.

Cortez (2011) reported the activity of two strains of fungi, P. chrysogenum and Diplodia sp. against Gram positive and Gram negative bacteria in fermented PD broth after $72 \mathrm{~h}$ under stirring of $180 \mathrm{rpm}$. The author relates the presence of the activity with the pigment produced by the organism. Corroborating this work, He et al. (2013) reported the isolation of a substance produced by Aspergillus spp., it was active against various microorganisms in the soil. The authors describe the substance isolated as an Anshamicyna and highlight its effectiveness in combating fungi and actinomycetes, human pathogens. Unlike this work, Kuephadungphan et al. (2014) reported the activity of the extract of the fungus Gibellula pulchra EPF083 against methicillin resistant S. aureus SK - 1 in Sabouraud broth under static condition for $48 \mathrm{~h}$. The authors highlight the importance of this kind of fungus because it is a pathogen of invertebrates.

The secondary metabolism of microorganisms is extremely diverse, providing the discovery of new compounds and new classes of compounds (Prabha et al., 2009). However, the production of secondary metabolites by the fungus depends intrinsically on the conditions used for their growth and development (time of incubation, culture medium composition, temperature, $\mathrm{pH}$ ) (Petit, 2009). Penicillium sp. was grown in liquid medium under stirring, at $\mathrm{pH} 7.0$ with incubation time of 5 days. Glucose and inoculum component experiment was varied so that the line was subjected to growth and production of metabolites in different conditions. Thus, multivariate methodology was used to vary growth conditions and to verify how these variations influence the production of secondary metabolites by the fungus strain. Once the incubation period was complete, the culture medium for each experiment was filtered separating the biomass from the liquid medium. The analyses were performed using antimicrobial test, tested with 3 strains of $S$. aureus (ORSA). It was observed that for the 11 runs, only the races of the central points $(9,10$ and 11 ) showed zone of inhibition of 10.5, 11 and 10.8 $\mathrm{mm}$ respectively for $S$. aureus 70914,$25 ; 14$ and 13.9 $\mathrm{mm}$ respectively for $S$. aureus 730 and $9.75,10$ and 10.2 respectively for S. aureus 733 (Figure 4). The results verified that race 10 is the only one that showed a $\mathrm{pH}$ of 7.7 lower than the other races. It was remaining an alkaline environment that favors the production of secondary metabolites, inhibiting the growth of the test microorganism. The response surface graph explains the low activity of growth on PDA medium, since the glucose present in the medium usually has an inhibitory effect on repressor and use of other carbon sources of subsequent metabolism of other compounds of this medium, causing retardation of fungal growth. However, the PDA proved to be a good medium when the culture biomass formation was desired. Based on the results, it can be suggested that the PDA medium has a minimal amount of glucose $(<0.1)$ and variation of inoculum $(<2)$, where the main goal is to deliver growth metabolite within a short space of time. However, if the aim is to analyze reproductive structures, it is suggested that PDA is employed, because it permits rapid sporulation.

One explanation for the inhibition of growth of Penicillium was influenced by the independent variables, as carotenoid biosynthesis (fungi have a significant potential for the biotechnological production of carotenoids, because yellow pigments accumulate during growth) naturally changes the $\mathrm{pH}$ of the medium. The $\mathrm{pH}$ is one of the most important environmental parameters that influence growth and product formation.

The results of the optimization of the experimental design (Figure 5) are expressed in Statistic 6.0 ANOVA; as noted, the concentrations of the dependent and independent variables are done in eleven repetitions. The Pareto chart shows how the variables influence the process, either positively or negatively.

In this case, the inoculum and glucoses variables influence negatively the process, which means that their low amount is best for antibiotic production by the fungus. The response surface figures show the trend in which the process should be conducted (Figure 6).

In this case, it is observed from the graphical response 


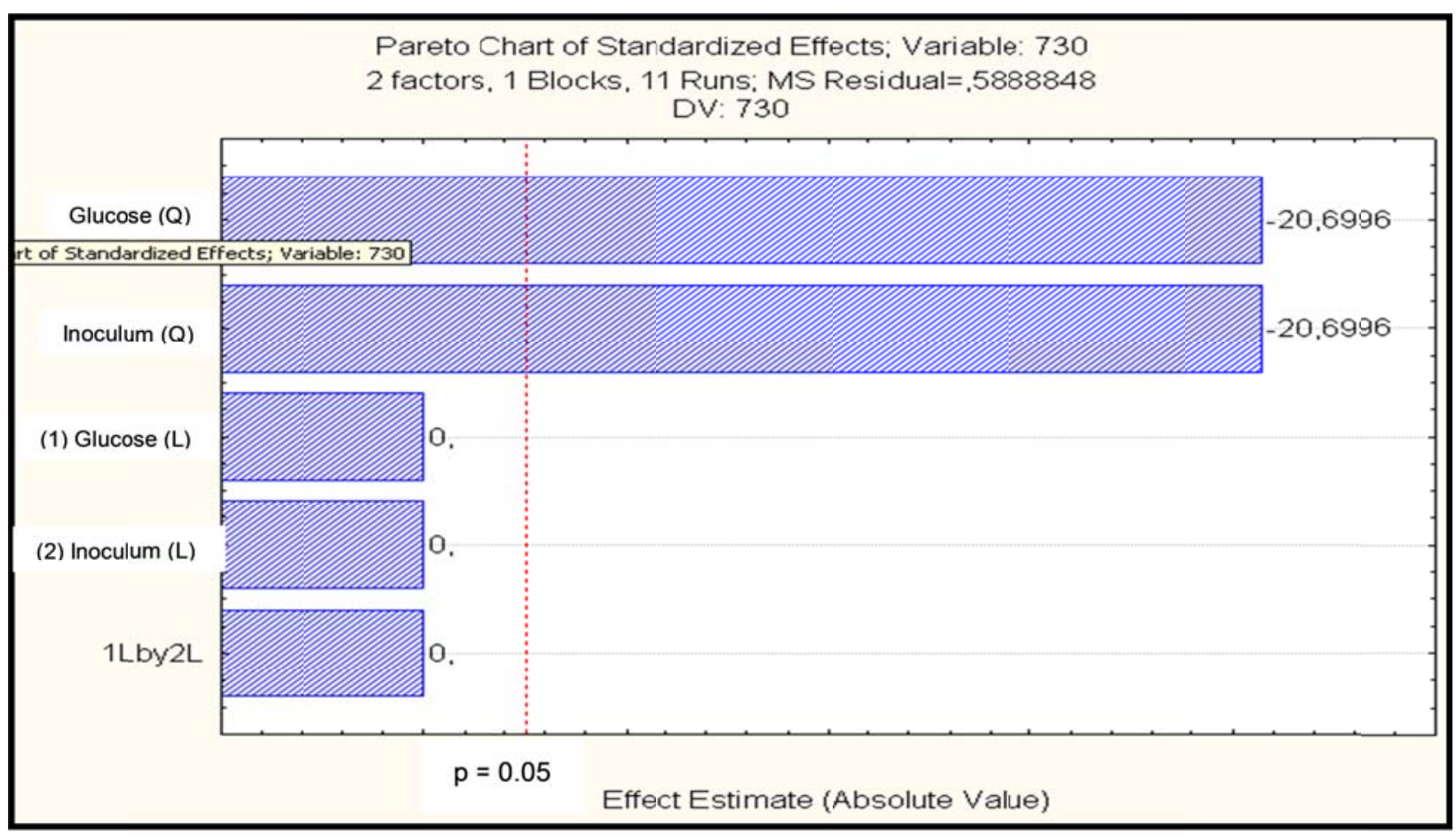

Figure 5. Pareto and standardized effects using glucose and inoculums which bustle as the dependent variable by Penicillium sp.

Fitted Surface; Variable: 730

2 factors, 1 Blocks, 11 Runs; MS Residual=, 5888848

DV: 730

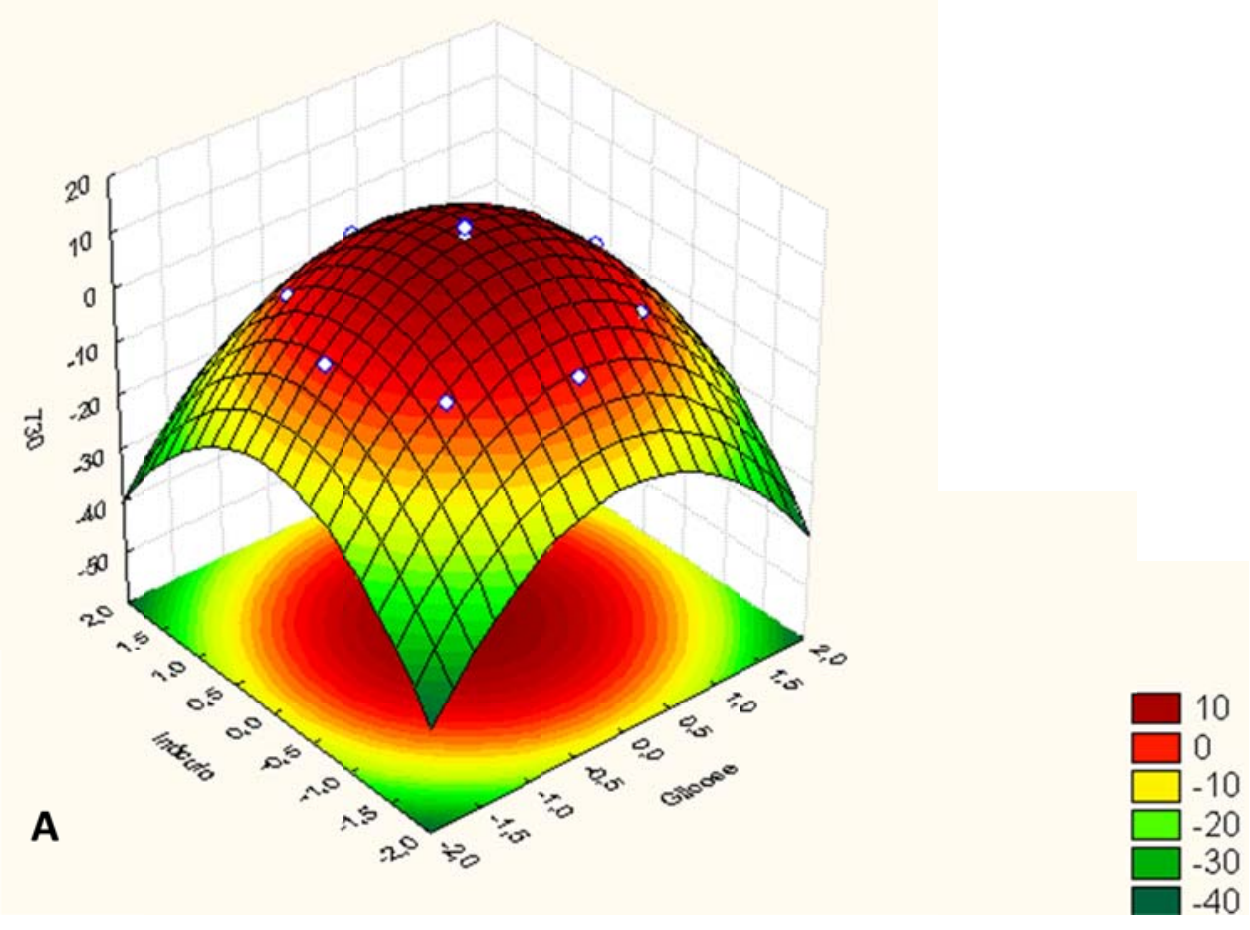

Figure 6. Surface response optimization means for PD production of bioactive compounds by $S$. aureus (ORSA, A - 730, B-733 and C-709). 
Fitted Surface; Variable: 733

2 factors, 1 Blocks, 11 Runs; MS Residual=, 1376553

DV: 733

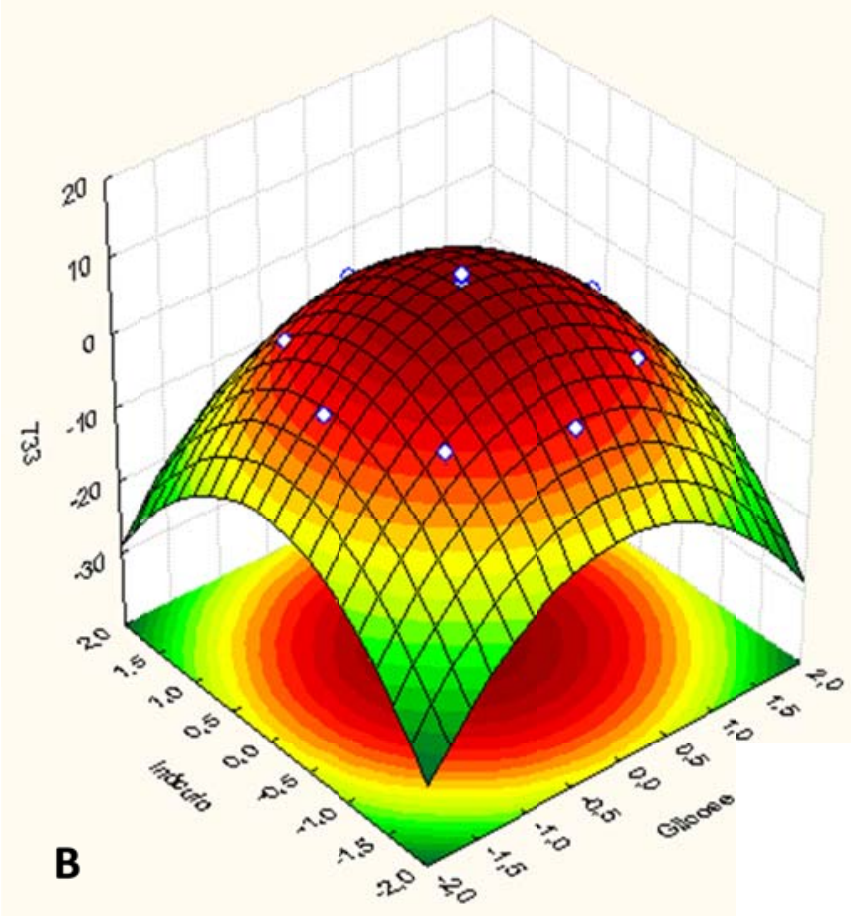

Fitted Surface; Variable: 709

2 factors, 1 Blocks, 11 Runs; MS Residual= $=, 1735408$

DV: 709

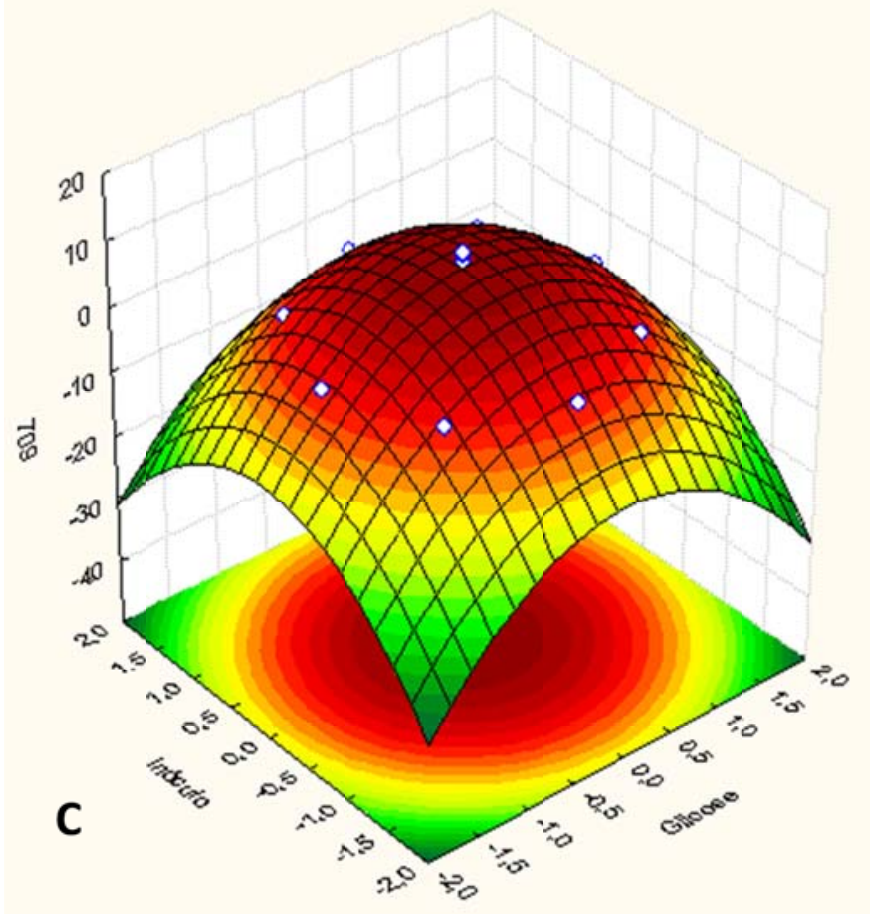

Figure 6. Contd. 
surface that lower amount of glucose and inoculum will lead to a better production of the metabolite. It can be seen in the figure that in response variable surface 733 (arrow) greater halo (red top) is present when glucose is between zero and 0.5 , likewise the inoculum.

\section{Conclusion}

Filamentous fungi showed a preference for growth in PD broth having a good biomass yield and sporulation. Penicillium $\mathrm{sp}$ produce secondary metabolites that inhibit the growth of $S$. aureus (ORSA). Glucose amounts greater than $0.1 \mathrm{~g}$ had an inhibitory effect on the growth and production of metabolite by the fungus.

\section{Conflict of Interests}

The authors have not declared any conflict of interests.

\section{REFERENCES}

Bauer AW, Kirby WM, Sherris JC, Turck M (1966). Antibiotic susceptibility testing by a standardized single disk method. Am. J. Clin. Pathol. 45:493-496.

Bhimba BV, Franco DAAD, Mathew JM, Jose GM, Joel EL, Thangaraj $M$ (2012). Anticancer and antimicrobial activity of mangrove derived fungi Hypocrea lixii VB1. Chin. J. Nat. Med. 10(1):77-80.

Bills GF, Gloer JB, An Z (2013). Coprophilous fungi: antibiotic discovery and functions in an underexplored arena of microbial defensive mutualism. Curr. Opin. Microbiol. 16:549-565.

Catão RMR, Silva PMF, Feitosa RJP, Pimentel MC, Pereira HS (2013). Prevalence of Hospital-Acquired Infections Caused by Staphylococcus aureus and Antimicrobial Susceptibility Profile. J. Nursing UFPE online Recife 7(6):5257-5264.

Cortez FL (2011). Produção e Análise dos Metabólitos Secundários de Fungos Filamentosos. Dissertação de Mestrado, 130f.

De Paris LD, Scheufele FB, Teixeira Jr A, Guerreiro TL, Hasan SDM (2012) Produção de complexos enzimáticos por $A$. niger a partir de soja por fermentação em estado sólido. Acta Scientiarum. Technology, Maringá, v. 34, n. 2, p. 193-200, Apr.-June,.

Demian AL, Adrio JL (2008). Contributions of Microorganisms to Industrial Biology. Mol. Biotechnol. 38:41-55.

Fachin AL, Contel EP, Martinez RNM (2001). Effect of sub-mics of antimycotics on expression of intracellular esterase of Trichophyton rubrum. Med. Mycol. 39 (1), 129-133.

Ferreira AM, Andrade D, Rigotti MA, de Almeida MTG (2011). Staphylococcus aureus resistente à meticilina em superfícies de uma Unidade de Terapia Intensiva. Acta Paul Enferm 24(4):453-458.

Fitsum S, Amin M, Selvaraj T, Alemayehu A (2014). In vitro Evaluation of some Fungicides and Bioagentes against common bean anthracnose (Colletotrichum lindemuthianum Sacc. and Magnus) Briosi and Cavara. Afr. J. Microbiol. Res. 8(20):2000-2005.
Gao M, Su R, Wang K, Li X, Lu W (2013). Natural antifouling compounds produced by a novel fungus Aureobasidium pullulans $\mathrm{HN}$ isolated from marine biofilm. Mar. Pollut. Bull. 77:172-176.

Griffin DH (1993). Fungal Physiology: John W, Sons, p. 458.

Hageskal G, Lima N, Skaar I. The study of fungi in drinking water. The British Mycological Society. Published by Elsevier Ltd. All rights reserved.doi:10.1016/j.mycres.2008.10.02.

He L, Liu Na, Wang Y, Xu HB, Yu Na (2013). Isolation an antimicrobial action of endophytic fungi from Sophora flavescens and effects on microorganism circumstances in soil. Procedia Environ. Sci. 18:264270.

Kuephadungphan W, Phongpaichit S, Luangsa-ard JJ, Rukachaisirikul $V$ (2014). Antimicrobial activity of invertebrate-pathogenic fungi in the genera Akanthomyces and Gibellula. Mycoscience 55:127 - 133.

Paterson RRM, Venâncio A, Lima N (2005). A novel identification system based on 318 penicillia strains using the isoepoxydon dehydrogenase gene and patulin production. Rev. Iberoam. Micol. 23:155-159.

Pereira VJ, Basílio MC, Fernandes D, Domingues M, Paiva JM, Benoliel MJ, Crespo MT, San Romão MV (2009). Occurrence of filamentous fungi and yeasts in three different drinking water sources. Water Res. 43 (15):3813-3819,

Pereira VJ, Fernandes D, Carvalho G, Benoliel MJ, San Romão MV, Barreto Crespo MT (2010) Assessment of the presence and dynamics of fungi in drinking water sources using cultural and molecular methods. Water Res. 44 (17):4850-4859.

Petit P (2009). Novel antimicrobial secondary metabolites from a Penicillium sp. isolated from Brazilian cerrado soil. Electron. J. Biotechnol. 12:1-9.

Pimenta EF, Seleghim MHR, Roberto AG, Berlinck GS (2008). Sociedade Brasileira de Química. Otimização das condições de crescimento e produção de metabólitos secundários por Penicillium oxalicum e $P$. citrinum de origem marinha.

Prabha D, Souza DL, Kamat T, Rodrigues C, Chandrakant NG (2009). Batch culture fermentation on Penicillium chrysogenum and a report on the isolation, purification, identification antibiot activity on citrinin. Indian J. Mar. Sci. 38:38-44.

Silva AL, Szajubok AF, Yamamura E (2006). Toxinas fúngicas em sistemas de tratamento de água. Companhia de Saneamento Básico do Estado de São Paulo.

Thibaut S, Caillon J, Huart C, Grandjean G, Lombrail P, Potel G, et al. (2010). Susceptibility to the main antibiotics of Escherichia coli and Staphylococcus aureus strains identified in community acquired infections in France (MedQual, 2004 2007). Med. Mal. Infect. 40 (2):74-80.

Tortorta GJ, Funke BR, Case CL (2000). Microbiologia. $6^{\circ}$ ed. Porto Alegre. Atrmed.

Wilson GS, Raftos DS, Nair SV (2011). Antimicrobial activity of surface attached marine bacteria in biofilms. Microbiol. Res. 166:437-448. 